\title{
STUDI PERBANDINGAN PEMECAHAN MASALAH MATEMATIS SISWA MENGGUNAKAN MODEL PEMBELAJARAN CREATIVE PROBLEM SOLVING (CPS) DAN MODEL PEMBELAJARAN LANGSUNG DI KELAS VII SMPN 6 KOTA JAMBI
}

\author{
Novia Eka Putri ${ }^{1}$, Zulyadaini $^{2}$, Relawati ${ }^{3}$ \\ Program Studi Pendidikan Matematika, FKIP, Universitas Batanghari ${ }^{1,2,3}$ \\ Jl. Slamet Riyadi No.1 Broni Jambi \\ Email: Noviaekaputri1@gmail.com
}

\begin{abstract}
ABSTRAK
Penelitian ini merupakan penelitian eksperimen. Populasi dalam penelitian ini adalah seluruh kelas VII SMP Negeri 6 Kota Jambi Tahun Ajaran 2017/2018. Pengambilan sampel menggunakan simple random sampling sedangkan sampel penelitian yang terambil adalah kelas VII C dan VII D, dimana dua kelas sampel ini diberikan perlakuan yang berbeda. Penelitian ini untuk mengetahui perbandingan rata-rata hasil siswa yang menerapkan Model Pembelajaran Creative Problem Solving (CPS) dan Model Pembelajaran Langsung. Dari hasil penelitian yang dilakukan Post-test nilai rata-rata untuk kelas Eksperimen adalah 63 dengan simpangan baku 21,71 dan kelas kontrol rata-ratanya adalah 53,66 dengan simpangan baku 22,01 Serta dari hasil uji Hipotesisnya diperoleh $\mathrm{t}_{\text {hitung }}$ sebesar 1,801 dan $\mathrm{t}_{\text {tabel }}$ sebesar 1,67 pada taraf nyata 0,05. Dari hasil perhitungan itu terlihat bahwa $t_{\text {hitung }}$ lebih besar dari $\mathrm{t}_{\text {tabel }}$ maka $\mathrm{H}_{1}$ diterima. Berdasarkan hasil akhir dapat disimpulkan bahwa kemampuan pemecahan masalah matematika siswa yang menggunakan Model pembelajaran Creative Problem Solving (CPS) lebih baik dari pada siswa yang menggunakan Model pembelajaran Langsung pada siswa kelas VII SMPN 6 Kota Jambi Tahun Ajaran 2017/2018.
\end{abstract}

Kata Kunci :

Kemampuan Pemecahan Masalah Matematis, Model Pembelajaran Creative Problem Solving (CPS)

\begin{abstract}
This research is an experimental research. Population in this research is all students of class VII SMPN 6 Kota Jambi Academic Year 2017/2018. Sampling using simple random sampling while the research samples are taken class VII C and VII D. where two classes of samples are given different treatment. From the results of research conducted the average value for the experimental class is 63 with standard deviation 21,71 and the average control class is 53,66 with standard deviation 22,01 and from the results of hypothesis test obtained $t_{\text {count }}$ of 1,801 and table of 1,67 at the real level of 0,05. From the calculation it is seen that $t_{\text {count }}$ greather than $t_{\text {table }}$ then $H_{l}$ accepted. Based on the final result, it can be concluded that the problem solving ability of mathematics students using learning model Creative Problem Solving (CPS) is better than the Direct learning model in students of grade VII SMPN 6 Kota Jambi.
\end{abstract}

Keywords:

Mathematical Problem Solving Ability, learning model Creative Problem Solving (CPS)

\section{PENDAHULUAN}

Pendidikan adalah sebagai usaha sadar dan terencana untuk mewujudkan suasana belajar dan proses pembelajaran untuk peserta didik secara aktif mengembangkan potensi dirinya untuk memiliki kekuatan spiritual keagamaan, pengendalian diri, kepribadian, kecerdasan, akhlak mulia, serta keterampilan yang diperlukan dirinya dan masyarakat, bangsa dan negaranya.
Pendidikan hendaknya mampu mengembangkan bakat yang dimiliki peserta didik secara optimal sehingga peserta didik dapat mengembangkan potensi diri yang dimilikinya menjadi suatu prestasi yang memiliki nilai jual (Shoimin, 2014:15).

Matematika merupakan salah satu ilmu yang mempunyai peranan penting dalam kehidupan. Matematika membantu orang untuk berpikir logis dan memecahkan 


\section{$\pi$ (Phi)}

masalah melalui fungsi matematika itu sendiri. Menurut Cornelius, sebagaimana dikutip oleh Abdurrahman (2003: 253), lima alasan perlunya belajar matematika karena matematika merupakan (1) sarana berpikir yang jelas dan logis, (2) sarana untuk memecahkan masalah kehidupan sehari-hari, (3) sarana mengenal pola-pola hubungan dan generalisasi pengalaman, (4) sarana untuk mengembangkan kreativitas, dan (5) sarana untuk meningkatkan kesadaran terhadap perkembangan budaya. Salah satu kemampuan yang penting dimiliki siswa adalah kemampuan pemecahan masalah.

Untuk meningkatkan

hasil pembelajaran matematika, diperlukan kegiatan mengembangkan bahan ajar yang digunakan. Bahan ajar merupakan aspek penting dalam proses pembelajaran, karena didalamnya mencakup materi pelajaran yang telah disusun secara sistematis. Salah satu bahan ajar yang digunakan guru untuk mengaktifkan proses pembelajaran adalah Lembar Kerja Siswa (LKS).

Holmes (Fauzan, 2011) pemecahan masalah dalam matematika adalah proses menemukan jawaban dari suatu pertanyaan yang terdapat dalam suatu cerita, teks, tugastugas, dan situasi-situasi dalam kehidupan sehari-hari. Lebih lanjut Holmes menjelaskan bahwa masalah-masalah yang dipecahkan meliputi semua topik dalam matematika baik dalam bidang geometri dan pengukuran, aljabar, bilangan (aritmatika), maupun statistika. Disamping itu siswa juga perlu berlatih memecahkan masalah-masalah yang mengaitkan matemtika dengan sains (natural sciene, dan social sciene).

Pemecahan masalah (problem solving) merupakan komponen yang sangat penting dalam matematika. Secara umum, dapat dijelaskan bahwa pemecahan masalah merupakan proses menerapkan pengetahuan (knowledge) yang telah diperoleh siswa sebelumnya ke dalam situasi yang baru. Pemecahan masalah juga merupakan aktivitas yang sangat penting dalam pembelajaran matematika, karena tujuan belajar yang ingin dicapai dalam pemecahan masalah berkaitan dengan kehidupan seharihari.

Menurut Killen (Susanto, 2013:197), "Pemecahan masalah sebagai strategi pembelajaran adalah suatu teknik dimana masalah digunakan secara langsung sebagai alat untuk membantu siswa memahami materi pelajaran yang sedang mereka pelajari". Dengan pendekatan pemecahan masalah ini siswa dihadapkan pada berbagai masalah yang dijadikan bahan pembelajaran secara langsung agar siswa menjadi peka dan tanggap terhadap semua persoalan yang dihadapi siswa.

Pemecahan masalah memberikan manfaat yang besar kepada siswa dalam melihat relevansi antara matematika dengan mata pelajaran yang lain, serta kehidupan dunia nyata. Pemecahan masalah merupakan sarana sekaligus target dari pembelajaran matematika di sekolah. Sebagai sarana, pemecahan masalah memungkinkan siswa untuk mengkonstruksi ide-ide matematis. Di samping itu, suatu masalah dapat mengarahkan siswa untuk melakukan investigasi, mengeksplorasi pola-pola, dan berpikir secara kritis. Untuk memecahkan masalah, siswa perlu melakukan pengamatan yang cermat, membuat hubungan, bertanya, dan menyimpulkan.

Secara umum pemecahan masalah yang sering digunakan adalah strategi yang dikemukakan oleh Polya (Susanto, 2013:202) dengan menyebutkan ada empat langkah dalam pembelajaran pemecahan masalah,yaitu: (1) Memahami masalah (2) Merencanakan penyelesaian

Melaksanakan rencana (4) Memeriksa kembali proses dan hasil.

Berdasarkan langkah Polya tersebut dalam pemecahan masalah matematis ada beberapa indikator pemecahan masalah menurut Sumarmo (Fauzan, 2011), yaitu sebagai berikut: (1) Mengidentifikasi unsurunsur yang diketahui, yang ditanyakan dan 


\section{$\pi$ (Phi)}

kecukupan unsur yang diperlukan; (2) Merumuskan masalah matematika atau menyusun model matematika; (3) Menerapkan strategi untuk menyelesaikan berbagai masalah dalam atau luar matematika; (4) Menjelaskan atau menginterpretasikan hasil permasalahan menggunakan matematika secara bermakna. Guna mengevaluasi kemampuan pemecahan masalah matematis siswa.

Model pembelajaran yang digunakan disini adalah Model Pembelajaran Creative Problem Solving (CPS). Menurut Shoimin (2014:56) Creative Problem Solving (CPS) merupakan variasi dari pembelajaran dengan pemecahan masalah melalui teknik sistematik dalam mengorganisasikan gagasan kreatif untuk menyelesaikan suatu permasalahan.

Model CPS adalah suatu model pembelajaran yang melakukan pemusatan pada pengajaran dan keterampilan pemecahan masalah yang diikuti dengan penguatan keterampilan (Shoimin,2014:56). Model Pembelajaran CPS memiliki kelebihan dan kekurangan (Shoimin,2014:57).

Kelebihan model pembelajaran CPS adalah: (1) Melatih siswa untuk mendesain suatu penemuan; (2) Berpikir dan bertindak kreatif; (3) Memecahkan masalah yang dihadapi secara realistis; (4) Mengidentifikasi dan melakukan penyelidikan; (5) Menafsirkan dan mengevaluasi hasil pengamatan; (6) Merangsang perkembangan kemajuan berpikir siswa untuk menyelesaikan masalah yang dihadapi dengan tepat; (7) Dapat membuat pendidikan sekolah lebih relevan dengan kehidupan, khususnya dunia kerja. Sedangkan kekurangan dari model pembelajaran CPS adalah: (1) Beberapa pokok bahasan sangat sulit untuk menerapkan metode pembelajaran ini. Misalnya keterbatasan alat-alat laboratorium menyulitkan siswa untuk melihat dan mengamati serta menyimpulkan kejadian atau konsep tersebut; (2) memerlukan alokasi waktu yang lebih panjang dibandingkan dengan metode pembelajaran yang lain.

Dapat disimpulkan bahwa model pembelajaran creative problem solving merupakan model pembelajaran yang menumbuhkan kreativitas dan keterampilan siswa dalam menyelesaikan berbagai masalah dalam belajar.

Menurut Shoimin (2014:57) Tahapan yang perlu ditempuh dalam model pembelajaran CPS adalah klarifikasi masalah, pengungkapan pendapat, evaluasi dan pemilihan, implementasi. Sintaks model pembelajaran CPS adalah:

1. Klarifikasi masalah : klarifikasi masalah meliputi pemberian penjelasan kepada siswa tentang masalah yang diajukan agar siswa dapat memahami tentang penyelesaian seperti apa yang diharapkan.

2. Pengungkapan pendapat : pada tahap ini siswa dibebaskan untuk mengungkapkan pendapat tentang berbagai macam strategi penyelesaian masalah.

3. Evaluasi dan Pemilihan : pada tahap evaluasi dan pemilihan, setiap kelompok mendiskusikan pendapat-pendapat atau strategi-strategi mana yang cocok untuk menyelesaikan masalah.

4. Implementasi : pada tahap ini siswa menentukan strategi mana yang dapat diambil untuk menyelesaikan masalah. Kemudian menerapkannya sampai menemukan penyelesaian dari masalah tersebut.

Dengan membiasakan siswa menggunakan tahapan yang kreatif dalam memecahkan masalah, diharapkan dapat membantu siswa untuk mengatasi kesulitan dalam mempelajari matematika.

Model pembelajaran langsung (Direct Instruction) dikenal dengan sebutan active teaching. Pembelajaran langsung juga dinamakan whole-class teaching. Penyebutan ini mengacu pada gaya mengajar dimana guru terlibat aktif dalam mengusung 


\section{$\pi$ (Phi)}

isi pelajaran kepada peserta didik dan megajarkannya secara langsung kepada seluruh siswa (Suprijono, 2011:46 ).

Pembelajaran yang dimaksudkan untuk menuntaskan dua hasil belajar yaitu penguasaan pengetahuan yang distrukturkan dengan baik dan penguasaan keterampilan. Ciri-ciri model pembelajaran langsung adalah sebagai berikut:

1. Adanya tujuan pembelajaran dan pengaruh model pada siswa termasuk prosedur hasil belajar

2. Sintaks atau pola keseluruhan dan alur kegiatan pembelajaran

3. Sistem pengolahan dan lingkungan belajar model yang diperlukan agar kegiatan pembelajaran tertentu dapat berlangsung dengan berhasil (Nur, 2000).

Menurut Suprijono (2011:51), kelima

fase pembelajaran langsung dapat

dikembangkan sebagai berikut:

1. Directing. Guru menjelaskan tujuan pembelajaran kepada seluruh kelas dan memastikan bahwa semua peserta didik mengetahui apa yang harus dikerjakan dan menarik perhatian peserta didik pada poin-poin yang membutuhkan perhatian khusus.

2. Instruction. Guru memberikan informasi dan menstruksasikan dengan baik.

3. Demonstrating. Guru menunjukkan, mendeskripsikan, dan mebuat model dengan menggunakan sumber serta display visual yang tepat.

4. Eksplaining and illustrating. Guru memberikan penjelasan-penjelasan akurat dengan tingkat kecepatan yang pas dan merujuk pada metode sebelumnya.

5. Questioning and discussing. Guru bertanya memastikan seluruh peserta didik ikut ambil bagian. Guru mendengarkan dengan seksama jawaban peserta didik dan merespons secara kontruktif untuk mengembangkan belajar peserta didik. Guru menggunakan pertanyaan-pertanyaan terbuka dan tertutup. Guru memastikan bahwa peserta didik dengan semua kemampuan yang dimilikinya terlibat dan memberikan kontribusi didalam diskusi. Guru memberikan waktu kepada peserta didik untuk memikirkan jawabannya sebelum peserta didik menjawab.

6. Consolidating. Guru mmemaksimalkan kesempatan menguatkan dan mengembangkan apa yang sudah diajarkan melalui berbagai macam kegiatan dikelas. Guru dapat pula member tugas-tugas yang difokuskan dengan baik untuk dikerjakan dirumah.

7. Evaluating pupil's responses. Guru mengevaluasi presentasi hasil kerja peserta didik.

8. Summarizing. Guru merangkum apa yang telah diajarkan dan apa yang sudah dipelajari peserta didik selama dan menjelang akhir pelajaran.

Berdasarkan pendapat di atas maka dapat disimpulkan bahwa pembelajaran langsung adalah model pembelajaran yang ditransformasikan langsung oleh guru kepada siswa dimana guru lebih aktif dalam proses pembelajaran.

\section{METODE PENELITIAN}

Metode yang digunakan pada penelitian ini adalah metode eksperimen. Di dalam penelitian ini, yang menjadi populasi penelitian adalah siswa kelas VII SMPN 6 Kota Jambi tahun ajaran 2017/2018. Teknik pengambilan sampel dalam penelitian ini adalah teknik simple random sampling (teknik acak). Pemilihan kelas eksperimen dan kelas kontrol digunakan secara undian, yang terpilih pertama sebagai kelas eksperimen yaitu kelas VII D yang dibelajarkan dengan model pembelajaran Creative Problem Solving (CPS), dan yang terpilih kedua adalah kelas kontrol yaitu kelas VII C merupakan kelas yang dibelajarkan menggunakan model pembelajaran langsung.

Menurut Sugiyono

penelitian eksperimen adalah penelitian yang 


\section{$\pi$ (Phi)}

di gunakan untuk mencari pengaruh perlakuan tertentu terhadap yang lain dalam kondisi yang terkendalikan. Dalam penelitian ini menggunakan rancangan penelitian yang berbentuk posttest-only control design. Dalam rancangan ini terdapat dua kelompok yang masing-masing dipilih secara random. Rancangan penelitian posttest-only control design seperti tabel 1 berikut :

Tabel 1. Rancangan penelitian

\begin{tabular}{c|c|c}
\hline Kelas & Treatment & Post-Test \\
\hline Eksperimen & $\mathrm{X}$ & $\mathrm{O}_{1}$ \\
Kontrol & - & $\mathrm{O}_{2}$ \\
\hline
\end{tabular}

\section{HASIL DAN PEMBAHASAN}

Dalam penelitian diperoleh dua hasil yaitu hasil penelitian yang diperoleh melalui analisis statistik deskriptif dan analisis statistik inferensial. Hasil analisis statistik deskriptif meliputi ukuran sampel, nilai tertinggi, nilai terendah, nilai rata-rata, simpangan baku dan varians. Sedangkan analisis statistik inferensial meliputi hasil uji-t.

Tabel 3. Uji Normalitas Kelas Sampel

\begin{tabular}{c|c|c|c|c|c}
\hline Kelas Sampel & $\mathrm{N}$ & $\mathrm{X}_{\text {hit }}^{2}$ & $\begin{array}{c}\mathrm{X}^{2} \text { tab } \\
\mathrm{A}=5 \%\end{array}$ & Hasil Uji & Ket \\
\hline Eksperimen & 34 & 4,8817 & 11,07 & $\mathrm{X}_{\text {hit }}^{2}<\mathrm{X}_{\text {tab }}^{2}$ & Normal \\
\cline { 4 - 5 } Kontrol & 35 & 5,0038 & 11,07 & $\mathrm{X}_{\text {hit }}^{2}<\mathrm{X}_{\text {tab }}^{2}$ & Normal \\
\hline
\end{tabular}

Berdasarkan keterangan perhitungan kecil dari $\mathrm{X}_{\text {tabel }}^{2}$ maka $\mathrm{H}_{0}$ diterima, sehingga pada tabel 3 di atas terlihat bahwa kedua kelas sampel mempunyai nilai $\mathrm{X}^{2}{ }_{\text {hitung }}$ lebih

Pada bagian ini dikemukakan karakteristik nilai yang diperoleh masingmasing variabel penelitian. Pengolahan data dilakukan secara manual yang menggunakan bantuan dari kalkulator.

Tabel 2. Karakteristik Nilai Hasil Post-Test Siswa

\begin{tabular}{c|c|c}
\hline \multirow{2}{*}{ Statistika } & $\begin{array}{c}\text { Kelas } \\
\text { Eksperimen }\end{array}$ & $\begin{array}{c}\text { Kelas } \\
\text { kontrol }\end{array}$ \\
\cline { 2 - 3 } Posttest & Posttest \\
\hline Ukuran Sampel & 34 & 35 \\
Rata-rata & 63 & 53,66 \\
Nilai Tertinggi & 94 & 91 \\
Nilai Terendah & 16 & 8 \\
Simpangan Baku & 21,71 & 22,01 \\
Varians & 528,97 & 483,06 \\
\hline
\end{tabular}

Berdasarkan Tabel 2 dapat dilihat bahwa jumlah siswa kelas eksperimen 34 orang dan jumlah siswa kelas kontrol 35 orang. Dari hasil posttest diperoleh nilai rata-rata kemampuan pemecahan masalah matematis pada kelas eksperimen adalah 63 dengan simpangan baku 21,71 dan nilai ratarata kelas kontrol sebesar 53,66 dengan simpangan baku 22,01.

Tabel 4 Uji Homogenitas Varians Data Hasil Post-test Kelas Sampel

\begin{tabular}{|c|c|c|c|c|c|}
\hline \multicolumn{2}{|c|}{ Varians } & $\boldsymbol{\alpha}$ & $\mathrm{F}_{\text {hitung }}$ & $\mathrm{F}_{\text {tabel }}$ & Keterangan \\
\cline { 1 - 2 } Eksperimen & Kontrol & & & & \\
\hline 528,97 & 483,06 & 0,05 & 1,09 & 1,80 & Homogen \\
\hline
\end{tabular}

kelompok mempunyai varians yang sama

Pada $\alpha=5 \%$ dengan $\mathrm{dk}$ pembilang = (homogen) maka $\mathrm{H}_{0}$ diterima.

Pengujian hipotesis dilakukan dengan na $-1=34-1=33$ dan dk penyebut $=n b-$ $1=35-1=34$, maka didapat $\alpha($ na-1);(nb-1) $=1,80$ karena $F_{\text {hitung }}<F_{\text {tabel }}$ yaitu $1,09<$ uji t. Hasil perhitungan uji hipotesis dapat dilihat pada tabel 5 berikut ini: 1,80, maka dapat disimpulkan bahwa kedua

Tabel 5. Perbandingan Rata-rata Hasil Tes Kemampuan Pemecahan Masalah Matematis Siswa

\begin{tabular}{|c|c|c|c|c|c|}
\hline Kelas & $\mathrm{N}$ & Rata-rata & $\mathrm{t}_{\text {hitung }}$ & $\mathrm{dk}$ & $\mathrm{t}_{\text {tabel }}$ \\
\hline Eksperimen & 34 & 63 & \multirow{2}{*}{1,801} & \multirow{2}{*}{67} & \multirow{2}{*}{1,67} \\
\hline Kontrol & 35 & 53,66 & & & \\
\hline
\end{tabular}




\section{$\pi$ (Phi)}

Berdasarkan hasil post-test bahwa hasil belajar matematika siswa kelas Eksperimen nilai rata-ratanya adalah 63 dengan simpangan baku 21,71 sedangkan pada kelas Kontrol memiliki rata-rata 53,66 dengan simpangan baku 22,01. Berdasarkan perhitungan tersebut terdapat perbandingan antara kelas Eksperimen dan kelas kontrol. Setelah dilakukan perhitungan dengan menggunakan uji-t, didapat $t_{\text {hitung }}$ sebesar $=$ 1,801 dan $t_{\text {tabel }}$ sebesar 1,67. Karena $t_{\text {hitung }}$ lebih tinggi dibanding $t_{\text {tabel }}$ sehingga $\mathrm{H}_{0}$ ditolak, dengan kata lain $\mathrm{H}_{1}$ diterima dengan tingkat kepercayaan 95\%. Hal ini berarti kemampuan pemecahan masalah matematis siswa kelas eksperimen lebih tinggi dibanding kelas kontrol.

Pada kelas eksperimen yang diajar menggunakan model pembelajaran Creative Problem Solving (CPS), siswa dibelajarkan untuk menumbuhkan kreativitas dan keterampilan siswa dalam menyelesaikan berbagai masalah dalam pembelajaran terutama matematika. Disini siswa menyelesaikan suatu masalah dengan cara berkelompok. Jadi setiap siswa dalam kelompok harus berperan aktif dalam menyelesaikan masalah yang ada dengan cara berdiskusi dan mengeluarkan pendapat masing-masing sehingga ketika diminta untuk menjelaskan mereka bisa menjelaskan hasil pekerjaan dengan tepat.

Sedangkan pada kelas kontrol jangankan siswa mau aktif dan menjelaskan suatu materi, untuk mengerjakan soal dipapan tulis saja siswa tidak berani maju ke depan kelas itu diakibatkan karena mereka terbiasa pasif hanya mencatat dan mendengarkan penjelasan guru saja. Adapun siswa yang lain merasa ngantuk dan sedikit bosan dan tidak memiliki motivasi dalam belajar matematika dikarenakan model pembelajaran yang diajarkan hanya berfokus pada guru itu sendiri.

Berdasarkan hasil penelitian yang dilakukan, model pembelajaran Creative Problem Solving (CPS), pada pokok bahasan segiempat dan segitiga yang diterapkan pada proses pembelajaran di kelas VII D SMPN 6 Kota Jambi memberikan dampak yang positif. Siswa mulai terbiasa berperan aktif dan kreatif dalam pembelajaran dan tidak takut untuk mengungkapkan pendapat mereka, sehingga siswa dapat menyelesaikan suatu permasalahan dengan baik dan siswa lebih bertanggung jawab terhadap hasil diskusi kelompoknya.

\section{SIMPULAN DAN SARAN}

Berdasarkan hasil analisis data dan pembahasan yang telah dilakukan pada bab sebelumnya dapat disimpulkan bahwa, ratarata kemampuan pemecahan masalah matematis siswa pada materi himpunan yang dibelajarkan dengan menggunakan model pembelajaran Creative Problem Solving (CPS) diperoleh nilai rata-rata 63 dengan simpangan baku 21,71 dan kemampuan pemecahan masalah matematis siswa pada materi segiempat dan segitiga yang dibelajarkan dengan menggunakan model pembelajaran langsung diperoleh nilai ratarata 53,66 dengan simpangan baku 22,01. Dengan menggunakan taraf signifikan $\alpha=0,05$ dan hasil perhitungan $t_{\text {hitung }}=1,801$ $>\mathrm{t}_{\text {tabel }}=1,67$ maka $\mathrm{H}_{1}$ diterima, dapat disimpulkan bahwa terdapat perbandingan kemampuan pemecahan masalah pada materi himpunan antar siswa yang menggunakan model pembelajaran Creative Problem Solving (CPS) dengan menggunakan model pembelajaran langsung. Hal ini berarti kemampuan pemecahan masalah siswa pada materi segiempat dan segitiga yang dibelajarkan dengan menggunakan model pembelajaran Creative Problem Solving (CPS) lebih baik dari pada pembelajaran dengan menggunakan model pembelajaran langsung pada siswa kelas VII SMPN 6 Kota Jambi.

Berdasarkan hasil penelitian yang didapatkan, peneliti menyampaikan beberapa saran yaitu: 
1. Guru diharapkan dapat menerapkan model pembelajaran khususnya pada materi segiempat dan segitiga yang membuat siswa menjadi aktif dalam belajar, salah satu model yang dapat digunakan yaitu model pembelajaran Creative Problem Solving (CPS).

2. Perlu adanya penelitian yang lebih lanjut sebagai pengembangan dari penelitian ini, terutama untuk meningkatkan kemampuan siswa dalam matematika.

\section{DAFTAR PUSTAKA}

Abdurahman, Mulyono. 2012. Anak Berkesulitan Belajar. Jakarta: Rineka Cipta.

Fauzan, Ahmad. 2011. Modul 1 Evaluasi Pembelajaran Matematika Pemecahan Masalah Matematika. Universitas Negeri Padang.

Shoimin, Aris. 2014. 68 Model Pembelajaran Inovatif Dalam Kurikulum 2013. Yogyakarta: ArRuzz Media.

Sugiyono, 2014. Metode Penelitian Pendidikan. Bandung: Alfabeta.

Supardi. 2014. Aplikasi Statistika dalam Penelitian Konsep Statistika yang lebih Komprehensif. Jakarta: Change Publication.

Suprijono, Agus, 2010. Cooperative Learning Teori dan Aplikasi PAIKEM . Yogyakarta : Pustaka Belajar.

Susanto, Ahmad. 2013. Teori Belajar \& Pembelajaran di Sekolah Dasar. Jakarta : Kencana. 